\title{
The Influence of Demographic Factor on Customer Service Quality Perception
}

\author{
Soniela GRAZHDANI, PhD Cand. \\ "Fan S. Noli" University, Shëtitorja "Rilindasit", 7001, Korçë, Albania \\ s.grazhdani@gmail.com
}

\section{Dr, Klaudeta MEROLLARI}

"Fan S. Noli" University, Shëtitorja "Rilindasit", 7001, Korçë, Albania

klaudetamerollari2010@hotmail.com

\begin{abstract}
Banks are continually striving for increased service quality in order to achive a competitive edge. In order to improve service quality is necessary understanding the factor that can influence the customer perception of the service quality. Marketing literature posits demographics as an important factor affecting customer service quality. Development of marketing strategies requires appropriate understanding of factor that can influence customer perception about service quality. Bank customers' needs according to their demography are still an unserved area. So, the purpose of this paper is to analysis the relationship between customer demographic characteristic such as gender, income, age and occupation and the bank service quality factors in Albania. For this purpose the data was collected through the survey of bank customers $(N=352)$ in two major cities in Albania. For measuring bank service quality perceptions a modified BSQ instrument was used. Statistical techniques used to determine the influence of demographic factor on customer perception of service quality were one way ANOVA and post hoc test. A significant difference was found in service quality perception by age groups whereas no significant difference was found on bases of gender, income and occupation. The results of the study enhance the understanding of service quality perception in Albanian banking industry and provide useful insight for the management and delivery of service quality. Also, the study finding can help bankers to design strategies that can fulfill customer requirements according to their gender, ages, and income and occupation characteristics.
\end{abstract}

Keywords: demographic factor, service quality, perception, banking, Albania

\section{Introduction}

The banking industry in Albania has undergone revolutionary changes due to liberalization and globalization measure since 1990. This measure has transformed the banking sector in Albania with strong contributions from government, private and foreign banks. Challenges coming from several fronts (e.g. structural, regulatory and customer related) make the banking landscape in Albania more competitive than ever before (Lleshanaku, 2008). The competitive situation makes it necessary for the banks to choose superior strategies and tactics in order to succeed. Because financial services compete in the market place with generally undifferentiated products, service quality becomes a primary competitive weapon (Stafford, 1996).

Development of marketing strategies requires appropriate understanding of factor that can influence customer perception about service quality. According to Meng (2009) demographic information shows that customers with different demographic characteristics have different perceptions of service quality. Gagliano (1994) and Webster (1989) found that age, gender and income were significantly related to service quality expectations for professional services. Demographics continue to be one of the most popular and well accepted bases for segmenting markets and customers (Belch, 2003). Given that demographic information is a fundamental and generally necessary consideration for segmentation and targeting (McCarty, 1993) understanding the effect of key demographic such as age, income and gender on customer perceptions of quality is important. 
It is important for bank managers to understand potential demographic effects in the evaluation of service quality for the development of effective marketing strategies, because without sound evidence and guidelines, managers may run the risk of making wrong decisions.

Therefore, the objective of this study is to investigate whether the demographical characteristics of customers such as gender, income, age and occupation influence the perception of service quality in Albanian banking industry.

This article is organized as follows: first we review prior theory and research relevant to service quality and demographic effects on service quality perceptions. Then we describe the method and present the results from our field of study. We conclude by discussing the finding and implications of the research.

\section{Literature review}

Service quality may be measured using multiple dimensions and attributes. Studies were conducted to explore and identify major attributes which determine success in offering a service (Parasuraman, 1985). The SERVQUAL model developed by Parasuram $(1985,1988)$ is the most cited and applied model for measuring service quality. The SERVQUAL model is composed by ten dimensions or determinants of service quality: reliability, access, understanding of the customer, responsiveness, competence, courtesy, communication, credibility, security, and tangible.

From reviewing the literature on the area of bank service quality measurements can be concluded that SERVQUAL was design as a universal scale applicable within and across a wide range of service settings has been used, replicated and modificated within specific banking sector.

To provide a lasting solution to the problem of the unsuccessful measurability of SERVQUAL, researchers agreed on a possible modification of the SERVQUAL model to suit the specific service settings (Bahia and Nantel, 2000; Jabnoun and Khalifa, 2005; Amin and Isa, 2008; Othman and Owen, 2001; Guo, Angus and Hair, 2008; Jabnoun and Al - Tamimi, 2003; Obaid, 2006; Karatepe, Yavas and Babakus, 2005).

To build their BSQ retail banking - specific metric Bahia and Nantel (2000), modificate the SERVQUAL model. Bahia and Nantel (2000) used a number of the SERVQUAL dimensions and incorporated additional dimensions in order to cover all the facets of the marketing mix. After modification, the dimensional structure of the BSQ scale was based on six dimensions effectiveness and assurance (which was composed from six SERVQUAL dimension competence; responsiveness; credibility; security; empathy; and communication), access, price, tangibles, service portfolio, reliability. While the dimensions use to define bank service quality may be similar in different countries, the relative importance and interpretation of the dimension differ from country to country.

The paper of Spathis (2004) investigated the effect of gender differences on customers' perceptions of service quality dimensions using the BSQ model developed by Bahia (2000). Surveys results indicated that customers' gender affects service quality perceptions and the relative importance attached to the various service quality dimensions.

Existing research models and measures may be inapplicable to other cultures unless the dimensionality of scales and reliability are demonstrated to exist (Douglas, 1983; Hui, 1985). For this study purposes was decided to use a modified BSQ instrument tested before for its reliability and validity in Albanian banking industry. This instrument differs from the original six dimensional BSQ instrument and is composed 28 items and four dimensions (1) Responsiveness and Informing, (2) Reliability and Security, (3) Commodities and (4) Effective Access (see table 11).

\subsection{Effect of demographics on the perception of service quality}

Although interest in life - style or psychographic information has increased among marketing practitioners, demographic information is still a fundamental and generally necessary consideration for segmentation and targeting (McCarty, 1993). Stafford (1996) stated that service quality continues to be a significant issue in the banking industry and identified distinct elements of bank service quality and ascertains which of those elements are most important to different demographic groups. 
Gupta (2011) found that gender, age, occupation, education level and income rated differently the dimensions of service quality of banks. Bhat (2005) found that there were differences across demographic characteristics in variable such as income and age.

Similarly, Javalgi (1990) found that older customers perceived personal service and financial advices important attributes of bank services. The pronounced emphasis on service interactions among the elderly was also highlighted in a study by Mattila (2003) where the lack of personal service in e-banking was found to be major barrier of internet banking adoption among mature customers.

Customers with different income levels have been found to have different perceptions of service quality (Scott, 1993). It is generally accepted that individuals with higher income levels also have higher education levels (Farley, 1964). Kotler (2010) suggest an increase in educated people leads to an increase in the demand for quality products. So, customers with higher income levels may perceive service quality differently from their lower income counterparts.

Previous research on gender effects on customer perceptions of service quality has produced somewhat conflicting results. For example, Stafford (1996) suggests service quality may be more important to women than to men when transacting business with bank. It was also noted within the research, that there are differences between men and women in terms of the degree of importance attached to service quality (Stafford, 1996). Spathis (2004) found that male clients of Greek banks have a more positive perception of the quality of the service they receive than do women clients. Also, there are several other examples in marketing literature that indicate that female customers tend to rate service quality lower when comparison is made for both genders (Lin, 2001; Tan, 2004; Juwaheer, 2011).

\section{Methodology}

The research has been conducted in two major cities in Albania. A total of 380 customers from 13 different banks have been approached from whom 352 correctly completed questionnaires have been obtained. The customers interviewed for the present study are selected through non probability sampling technique for four month. The service quality is assessed based on a modified BSQ model which was designed priory by the author for measuring bank service quality in Albania. The 28 items of this instrument were measured through a seven point Likert scale ranging from 1 - strongly disagree to 7 strongly agree. The score on each dimension is the mean of the sum of the corresponding items scores. Perceptions - only score rather than gap score $(P-E)$ was used since the perceptions only scale was the most appropriate for Albanian context. One way ANOVA test (testing the difference between the mean of two independent variables) were employed to examine if the service quality dimensions means varied among respondents with different demographic characteristics such as gender, age, occupation and income. For detailed analysis, post hoc analysis had been applied.

\section{Results}

The results revealed that there was a significant relationship between age and customer service quality perceptions, while there was not a relationship between gender, occupation, income and service quality perceptions.

The relationship between gender, income and occupation and bank service quality perceptions

Analysis of variance (table 2) exhibited that none of dimensions differed significantly on gender basis i.e. male and female respondents perceived the bank service quality dimensions as same. It means that no statistically significant difference was found between male and female means scores of service quality dimensions in Albanian banking industry.

Analysis of variance (table 2) depicted that none of the service quality dimensions differed significantly on the basis of income i.e. respondent from different group income grasped the bank service quality dimensions as same. Due to technology and communication advancement, respondent of different income level have no differences in perceptions regarding service features offered by banks.

Analysis of variance depicted that none of the service quality dimensions in Albanian banking industry differed significantly on the basis of occupation. 


\subsection{The relationship between service quality perception and age}

Analysis of variance presented in table 2 revealed that age had a influence on commodities and effective access perceptions and had no influence on Responsiveness/Informing and Reliability/Security perceptions of bank customers in Albania.

\subsection{The relationship between effective access perception and age}

Post hoc analysis (table 4) revealed that respondent of the age group $18-24$ years differ significantly from the respondent of age groups $35-44$ years, $45-54$ and $55-65$ years with respect to effective access perceptions of service quality for bank in Albania. Negative mean difference between the respondent of age groups $18-24$ years with the respondent of age groups $35-44$ years, $45-54$ and $55-65$ years shows that respondent of age group $35-44$ years, $45-54$ and 55 -65 years have higher mean scores than the respondent of age group $18-24$ years for effective access. Respondent of the age group $35-44$ years, $45-54$ and $55-65$ years had a more positive perception about the banks sufficient number of ATMs; convenient location of branches and ATMs; sufficient number of open tellers and interruption of the service than the respondent of age group $18-24$ years.

Post hoc analysis (table 4) revealed that respondent of the age group $25-34$ years differ significantly from the respondent of age groups $35-44$ years, $45-54$ years and $55-65$ years with respect to effective access perceptions of service quality for bank in Albania. Negative mean difference between the respondent of age groups $25-34$ years with the respondent of age groups $35-44$ years, $45-54$ years and $55-65$ years shows that respondent of age group $35-44$ years, $45-54$ years and $55-65$ years have higher mean scores than the respondent of age group $25-34$ years for effective access. Respondent of the age group $35-44$ years, $45-54$ years and $55-65$ years had a more positive perception about the banks sufficient number of ATMs; convenient location of branches and ATMs; sufficient number of open tellers and interruption of the service than the respondent of age group $25-34$ years.

\subsection{The relationship between Commodities perception and age}

Post hoc analysis (table 6) revealed that respondent of the age group $25-34$ years differ significantly from the respondent of age groups $45-54$ years and $55-65$ years with respect to commodities perceptions of service quality for bank in Albania. Negative mean difference between the respondent of age groups $25-34$ years with the respondent of age groups $45-54$ years and $55-65$ years shows that respondent of age group $25-34$ years have lower mean scores than the respondent of age group $45-54$ years and $55-65$ years for commodities.

Post hoc analysis (table 6 ) revealed that respondent of the age group over 65 years differ significantly from the respondent of age groups $45-54$ years and $55-65$ years with respect to commodities perceptions of service quality for bank in Albania. Negative mean difference between the respondent of age groups over 65 years years with the respondent of age groups $45-54$ years and $55-65$ years shows that respondent of age group over 65 years have lower mean scores than the respondent of age group $45-54$ years and $55-65$ years for commodities.

The mean score of Commodities and Effective Access for each age group are presented on table 6 and 8 .

So, the younger age groups have had lower mean scores for Effective Access items than the older ones because they like to spend their time in leisure activities.

\subsection{The relationship between Effective Access perception and Period dealing with the bank}

Post hoc analysis (table 8) revealed that respondent that have 6 month dealing with a bank differ significantly from the respondent that have 1 year and 2 year dealing with a bank with respect to effective access perceptions of service quality for bank in Albania. Positive mean difference between the respondent that have 6 month dealing with a bank have higher mean scores than the respondent that have 1 year and 2 year dealing with a bank for effective access.

Post hoc analysis (table 8) revealed that respondent that have 5 years dealing with a bank differ significantly from the respondent that have 1 year dealing with a bank with respect to effective access perceptions of service quality for bank in Albania. Positive mean difference between the respondent that have 5 year dealing with a bank have higher mean scores than the respondent that have 1 year dealing with a bank for effective access. So, the customer recently approached a bank and they who have a long period dealing with the bank perceive had a more positive perception about the banks 
sufficient number of ATMs; convenient location of branches and ATMs; sufficient number of open tellers and interruption of the service.

\subsection{The relationship between Commodities perception and Period dealing with the bank}

Post hoc analysis (table 9) revealed that respondent that have 2 years dealing with a bank differ significantly from the respondent that have 6 month, 1 year, 3-5 years, over 5 years dealing with a bank with respect to commodities perceptions of service quality for bank in Albania. Negative mean difference between the respondent that have 2 years dealing with a bank have lower mean scores than the respondent that have 6 month, 1 year, 3-5 years, over 5 years dealing with a bank for commodities. So, the managers have to deal with these group of customers in order to improve their perceptions levels related to bank visually appealing physical facilities; work environment; orderliness and cleanness of employees and premises; service information visually attractive and facile to understand and complete gamut of services.

\section{Conclusions}

Our objective was to determine whether demographic affect perceptions of the four dimensions of service quality in Albanian banking industry. The study found strong evidence of the effect of age on service quality perceptions. That is, effective access dimension of bank service quality were significantly higher for mature individuals compares to their younger counterparts. Overall, the findings suggest that service quality should be more closely tailored to age and not to other demographic characteristics.

The mean differences on the basis of age were significant for commodities and effective access perceptions. The finding that mature people had higher perceptions on effective access of bank service has several important implications. The high mean scores of the older age group for effective access indicated that they had a more positive perception about the bank visually appealing physical facilities; work environment; orderliness and cleanness of employees and premises; service information visually attractive and facile to understand and complete gamut of services.

The finding reinforces the need for banks managers to place an emphasis on the underlying dimensions of service quality and take into account the moderating effect of demographics.

Contrary to our expectations, no evidence for perceptions of bank service quality differed by gender, income and occupation was found. The failure to establish gender difference in perceptions of service quality has implications for treatment of customers in these service contexts. That is, results imply that stereotyping along gender lines may be inappropriate.

\subsection{Limitations and future research}

As is the case with any research, this study has several limitations. Neither psychographics nor the full range of demographic characteristics (e.g. education, marital status, and ethnicity) was included in this study. Thus, the inclusion of the full range of demographic and psychographics variables could also yield insights into segmentation possibilities. Further, the interaction effects within the demographic variables were not investigated. Yet this could be a worthy area of future research. Replication of this study with a larger random sample would increase the generalizability of the results.

Contrary to our expectations, we found no evidence that perceptions of bank service quality differed by gender, income, and occupation.

\section{References}

[1] Aldaigan, A. H., Buttle, F. A. (2002). SYSTRA-SQ: A new measure of bank service quality. International Journal of Service Industry Management, 13 (4), pp. 362-81.

[2] Amin, M., Isa, Z. (2008). An examination of the relationship between service quality perception and customer satisfaction. International Journal of Islamic and Middle Eastern Finance and Management, 1 (3), pp. 191-209.

[3] Angur, G. M., Nataraajan, R., Jahera J. S. (1999). Service quality in the banking industry: an assessment in a developing economy. International Journal of Bank Marketing, 17/3, pp.116-123 
[4] Avkiran, N.K. (1994). Developing an instrument to measure customer service quality in branch banking. International Journal of Bank Marketing, Vol. 12, No. 6, pp. 10-18

[5] Bahia, K., Nantel, J. (2000). A reliable and valid measurement scale for the perceived service quality of banks. International Journal of Bank Marketing, 18 (2), pp. 84-91.

[6] Farley, J.U. (1964. Why does 'brand loyalty' vary over products?. Journal of Marketing Research, Vol. 1 No. 4, pp. 9 14

[7] Gagliano, K.B., Itathcote, J., (1994), "Customer Expectations and Perceptions of Service Quality In Retail Apparel pecialty tores", Journal of Service Marketing, 8 (1), pp. 60-69.

[8] Gupta, K. K., Bansal, J. (2011). Effect of demographic variables on customer perceived internet banking service quality. Paradigm, XV(1\&2), 83-92.

[9] lacobucci , D., and Ostrom, A. (1993). Gender differences in the impact of core and relational aspects of services on the evaluation of service encounters. Journal of Consumer Psychology, Vol 2, No 3, pp. 257-286

[10] Javalgi, R. G., Belonax, J. J., Jr., Robinson, A. M. (1990). Mature consumers in the financial services marketplace Potential market segments", Journal of Professional Services Marketing, Vol 6, № 1, pp. 81-107

[11] Kotler, P., Armstrong, G. (2010) Principles of Marketing. 13th edn. London: Pearson.

[12] Lleshanaku, A. (2008). Service Quality Perspectives in Albanian Private Banking. ICMS, Vol. 1, No. 1, pp. 28

[13] Mattila, M., Karjaluoto, H. and Pento, T. (2003). Internet banking adoption among mature customers: early majority or laggards?. Journal of Services Marketing, Vol. 17 No 5, pp. 514 - 528

[14] Ogden, J., Ogden, D. (2005). Retailing: Integrated Retail Management. Boston: Houghton Mifflin Company.

[15] Scott, D., Sheiff, D. (1993). Service quality components and group criteria in local government", International Journal of Service Industry Management, Vol. 4, No. 4, pp. 42-53

[16] Spathis, C., Petridou, E., Glaveli N. (2004). Managing service quality in banks: customers gender effects. Managing Service Quality, Vol. 14, Iss: 1, pp.90 - 102

[17] Stafford, M. R. (1996). Demographic discriminators of service quality in the banking industry. Journal of Services Marketing, Vol. 10, Iss: 4, pp. 6 - 22

[18] Webster, C., (1989). Can Consumers be Segmented on the Basis of their Service Quality Expectations?. Journal of Service Marketing, 3 (2), pp. 35-53.'

\section{Tables}

Table 1: Respondents' Profile

\begin{tabular}{|l|l|l|}
\hline Demographic & Category & Percent \\
\hline \multirow{4}{*}{ Agender } & Male & 56.0 \\
\cline { 2 - 3 } & Female & 44.0 \\
\hline \multirow{5}{*}{ Monthly Income } & $18-24$ year & 9.7 \\
\cline { 2 - 3 } & $25-34$ year & 37.2 \\
\cline { 2 - 3 } & $35-44$ year & 29.8 \\
\cline { 2 - 3 } & $45-54$ year & 10.8 \\
\cline { 2 - 3 } & $55-65$ year & 10.8 \\
\cline { 2 - 3 } & Over 65 year & 1.7 \\
\hline & No income & 2.8 \\
\cline { 2 - 3 } & $19.000-25.000 \mathrm{ALL}$ & 5.4 \\
\cline { 2 - 3 } & $25.000-40.000 \mathrm{ALL}$ & 25.9 \\
\cline { 2 - 3 } & $40.000-60.000 \mathrm{ALL}$ & 31.8 \\
\hline
\end{tabular}




\begin{tabular}{|l|l|l|}
\hline \multirow{5}{*}{ Occupation } & $60.000-80.000 \mathrm{ALL}$ & 20.2 \\
\cline { 2 - 3 } & Over 80.000 ALL & 13.9 \\
\hline \multirow{5}{*}{ Period of dealing with the bank } & Employee & 31.0 \\
\cline { 2 - 3 } & Self - Employee & 4.8 \\
\cline { 2 - 3 } & Retired & 4.3 \\
\cline { 2 - 3 } & Student & 4.0 \\
\cline { 2 - 3 } & Housewife & 2.0 \\
\cline { 2 - 3 } & Sole trader & .3 \\
\cline { 2 - 3 } & SME owner & 4.5 \\
\cline { 2 - 3 } & Civil Servant & 24.1 \\
\cline { 2 - 3 } & Other & 25.0 \\
\hline & 3 month & 1.4 \\
\cline { 2 - 3 } & 6 month & 6.3 \\
\cline { 2 - 3 } & 1 year & 12.8 \\
\cline { 2 - 3 } & 2 years & 15.6 \\
\cline { 2 - 3 } & $3-5$ years & 26.7 \\
\cline { 2 - 3 } & More than 5 years & 37.2 \\
\hline
\end{tabular}

Table 2. ANOVA between Service Quality Dimensions and Gender, Age, Income, Occupation, Period Dealing With the Bank

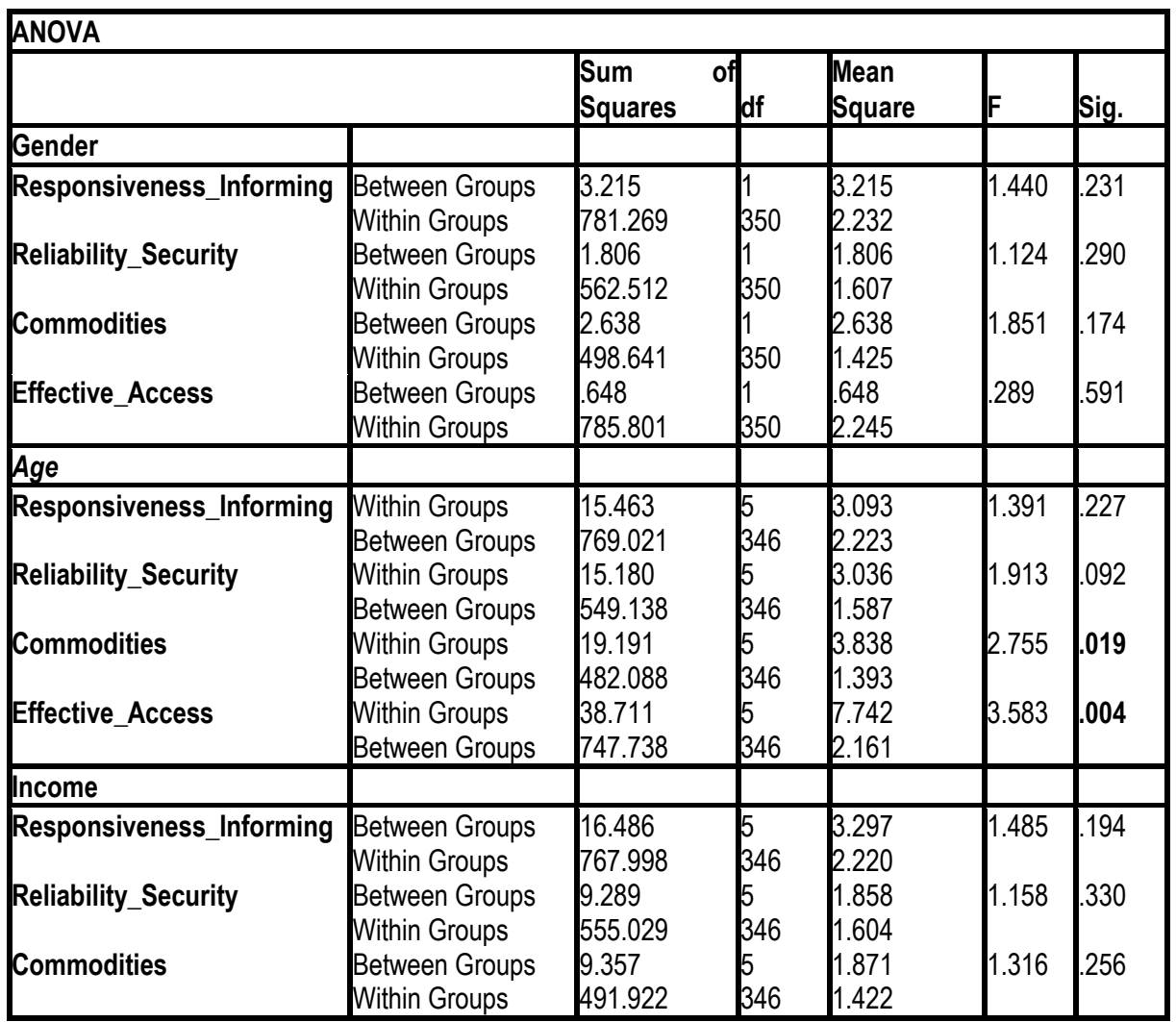




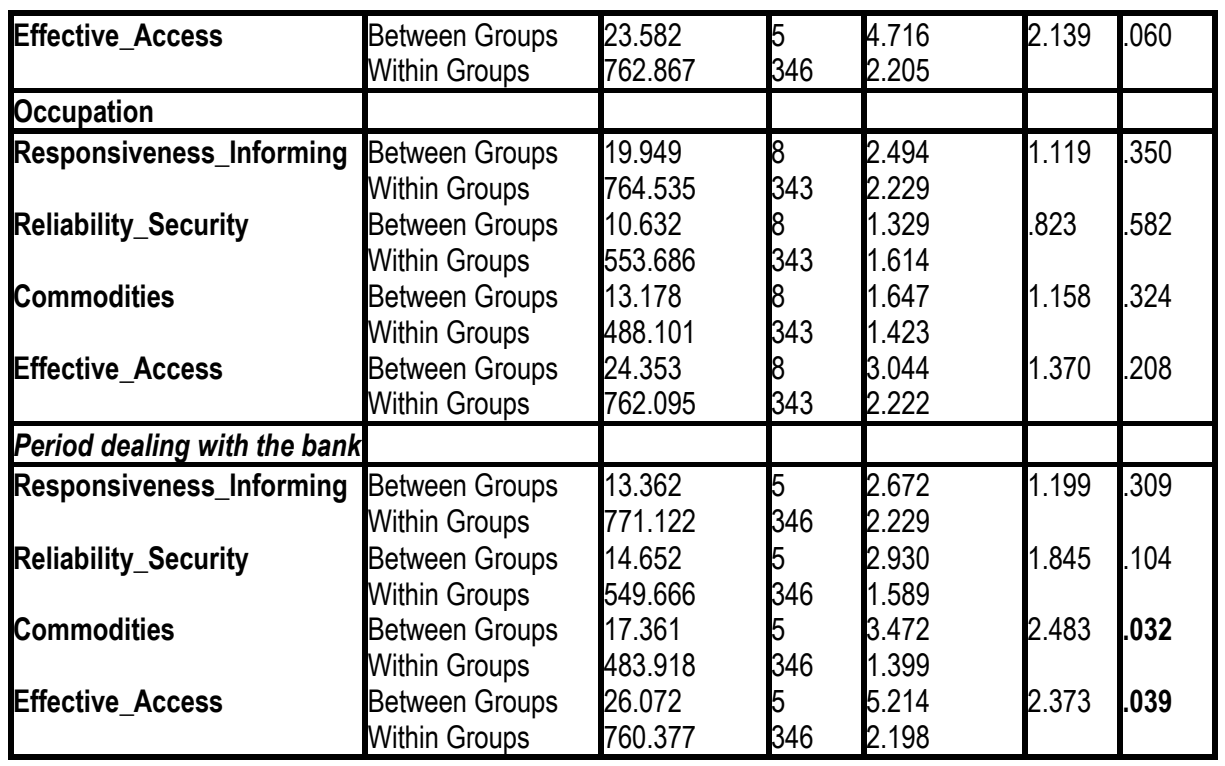

Table 3: Mean of Responsiveness_Informing, Reliability_Security, Commodities and Effective_Access

\begin{tabular}{|l|l|l|l|l|}
\hline Gender & Responsiveness_Informing & Reliability_Security & Commodities & Effective Access \\
\hline Female Mean & 4.7317 & 5.4497 & 5.6660 & 4.8249 \\
\hline Male Mean & 4.5392 & 5.3054 & 5.4916 & 4.9113 \\
\hline
\end{tabular}

Table 4: Post Hoc analysis of Age on Commodities - LSD Method

\begin{tabular}{|c|c|c|c|c|c|c|c|}
\hline \multirow{2}{*}{$\begin{array}{l}\text { Dependent } \\
\text { Variable }\end{array}$} & \multirow[t]{2}{*}{ (I) age } & \multirow[t]{2}{*}{$(\mathrm{J})$ age } & \multirow{2}{*}{$\begin{array}{l}\text { Mean } \\
\text { Difference } \\
\text { J) }\end{array}$} & \multirow{2}{*}{ 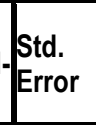 } & \multirow[b]{2}{*}{ Sig. } & \multicolumn{2}{|c|}{$95 \%$ Confidence Interval } \\
\hline & & & & & & $\begin{array}{l}\text { Lower } \\
\text { Bound }\end{array}$ & $\begin{array}{l}\text { Upper } \\
\text { Bound }\end{array}$ \\
\hline \multirow[t]{13}{*}{ Commodities } & \multirow[t]{5}{*}{18 - 24 year } & 25 - 34 year & 16929 & 22719 & .457 & .2776 & 6161 \\
\hline & & 35 - 44 year & -.07529 & 23292 & .747 & -.5334 & 3828 \\
\hline & & $45-54$ year & -31950 & 27865 & 252 & -.8676 & 2286 \\
\hline & & $55-65$ year & -.41950 & 27865 & .133 & -.9676 & 1286 \\
\hline & & Over 65 year & .86471 & .52268 & .099 & -.1633 & 1.8927 \\
\hline & \multirow[t]{5}{*}{25 - 34 year } & 18 - 24 year & .16929 & .22719 & .457 & -.6161 & 2776 \\
\hline & & 35 - 44 year & -.24458 & 15461 & .115 & -.5487 & .0595 \\
\hline & & 45 - 54 year & $.48879^{\star}$ & 21749 & .025 & -.9166 & -.0610 \\
\hline & & $55-65$ year & $.58879^{*}$ & 21749 & .007 & -1.0166 & -.1610 \\
\hline & & Over 65 year & 69542 & .49280 & .159 & .2738 & 1.6647 \\
\hline & \multirow[t]{3}{*}{35 - 44 year } & 18 - 24 year & .07529 & 23292 & .747 & .3828 & .5334 \\
\hline & & 25 - 34 year & 24458 & 15461 & .115 & -.0595 & .5487 \\
\hline & & 45 - 54 year & -.24421 & 22346 & .275 & -.6837 & 1953 \\
\hline
\end{tabular}




\begin{tabular}{|c|c|c|c|c|c|c|c|}
\hline \multirow{17}{*}{ 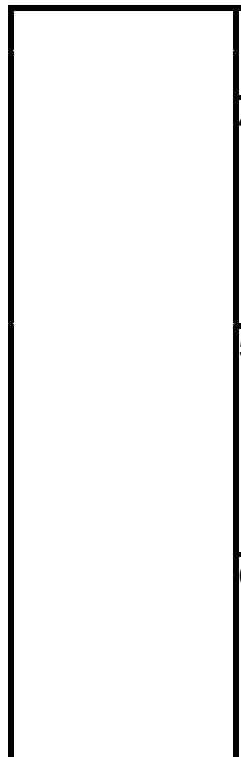 } & 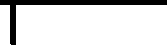 & 55 - 65 year & .34421 & 22346 & .124 &. .7837 & .0953 \\
\hline & 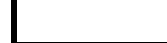 & Over 65 year & .94000 & .49547 & .059 & -.0345 & 1.9145 \\
\hline & 45 - 54 year & 18 - 24 year & 31950 & .27865 & .252 & .2286 & .8676 \\
\hline & & 25 - 34 year & $.48879^{\star}$ & 21749 & .025 & .0610 & 9166 \\
\hline & & 35 - 44 year & 24421 & .22346 & .275 & .1953 & 6837 \\
\hline & & $55-65$ year & .10000 & .27080 & .712 & .6326 & 4326 \\
\hline & & Over 65 year & $1.18421^{*}$ & .51854 & .023 & .1643 & 2.2041 \\
\hline & $55-65$ year & 18 - 24 year & .41950 & 27865 & .133 & -1286 & .9676 \\
\hline & & $25-34$ year & $.58879^{*}$ & 21749 & .007 & 1610 & 1.0166 \\
\hline & & 35 - 44 year & .34421 & .22346 & .124 & -.0953 & .7837 \\
\hline & & $45-54$ year & 10000 & .27080 & .712 & -.4326 & 6326 \\
\hline & & Over 65 year & $1.28421^{*}$ & .51854 & .014 & 2643 & 2.3041 \\
\hline & Over 65 year & $18-24$ year & .86471 & .52268 & .099 & -1.8927 & 1633 \\
\hline & & 25 - 34 year & -.69542 & .49280 & 159 & -1.6647 & 2738 \\
\hline & & 35 - 44 year & -.94000 & .49547 & .059 & -1.9145 & .0345 \\
\hline & & 45 - 54 year & $-1.18421^{*}$ & .51854 & .023 & -2.2041 & -.1643 \\
\hline & & $55-65$ year & $-1.28421^{*}$ & .51854 & .014 & -2.3041 & .2643 \\
\hline
\end{tabular}

Table 5: Mean of Commodities

\begin{tabular}{|l|l|l|l|l|l|l|}
\hline & $\mathbf{1 8}-\mathbf{2 4}$ year & $\mathbf{2 5 - 3 4}$ year & $\mathbf{3 5 - 4 4}$ year & $\mathbf{4 5 - 5 4 \text { year }}$ & $\mathbf{5 5 - 6 5}$ year & Over $\mathbf{6 5}$ year \\
\hline Mean & 5.5647 & 5.3954 & 5.6400 & 5.8842 & 5.9842 & 4.7000 \\
\hline
\end{tabular}

Table 6: Post Hoc analysis of age on Effective_Access - LSD Method

\begin{tabular}{|c|c|c|c|c|c|c|c|}
\hline \multirow[t]{2}{*}{ Dependent Variable } & \multirow[t]{2}{*}{ (I) age } & \multirow[t]{2}{*}{$(\mathrm{J})$ age } & \multirow{2}{*}{$\begin{array}{l}\text { Mean Difference } \\
(I-J)\end{array}$} & \multirow{2}{*}{ Std. Error } & \multirow{2}{*}{ Sig. } & \multicolumn{2}{|c|}{$95 \%$ Confidence Interval } \\
\hline & & & & & & Lower Bounc & Upper Bound \\
\hline \multirow[t]{16}{*}{ Effective_Access } & \multirow[t]{5}{*}{18 - 24 year } & 25 - 34 year & -.28362 & 28295 & .317 & -.8401 & .2729 \\
\hline & & 35 - 44 year & $-.66912^{*}$ & .29007 & .022 & -1.2396 & -.0986 \\
\hline & & $45-54$ year & $-.85333^{*}$ & 34703 & .014 & -1.5359 & -.1708 \\
\hline & & $55-65$ year & $-1.16254^{*}$ & 34703 & .001 & -1.8451 & -.4800 \\
\hline & & Over 65 year & .54412 & 65096 & .404 & -1.8244 & .7362 \\
\hline & \multirow[t]{5}{*}{25 - 34 year } & 18 - 24 year & .28362 & .28295 & .317 & -.2729 & .8401 \\
\hline & & $35-44$ year & $-38550^{*}$ & 19256 & .046 & -.7642 & -.0068 \\
\hline & & $45-54$ year & $-.56971^{*}$ & 27086 & .036 & -1.1025 & -.0370 \\
\hline & & $55-65$ year & $-.87892^{*}$ & 27086 & .001 & -1.4117 & -.3462 \\
\hline & & Over 65 year & -.26050 & 61374 & .672 & -1.4676 & .9466 \\
\hline & \multirow[t]{5}{*}{35 - 44 year } & 18 - 24 year & $.66912^{*}$ & 29007 & .022 & .0986 & 1.2396 \\
\hline & & 25 - 34 year & $38550^{*}$ & 19256 & .046 & .0068 & .7642 \\
\hline & & $45-54$ year & -.18421 & .27830 & .508 & -.7316 & .3632 \\
\hline & & 55 - 65 year & -.49342 & 27830 & .077 & -1.0408 & .0540 \\
\hline & & Over 65 year & 12500 & 61706 & .840 & -1.0887 & 1.3387 \\
\hline & 45 - 54 year & 18 - 24 year & $.85333^{\star}$ & 34703 & .014 & .1708 & 1.5359 \\
\hline
\end{tabular}




\begin{tabular}{|c|c|c|c|c|c|c|}
\hline & 25 - 34 year & $.56971^{*}$ & 27086 & .036 & .0370 & 1.1025 \\
\hline & 35 - 44 year & .18421 & 27830 & .508 & -.3632 & .7316 \\
\hline & $55-65$ year & -30921 & 33726 & .360 & .9725 & .3541 \\
\hline & Over 65 year & 30921 & 64580 & .632 & -.9610 & 1.5794 \\
\hline \multirow[t]{5}{*}{$55-65$ year } & 18 - 24 year & $1.16254^{*}$ & 34703 & .001 & .4800 & 1.8451 \\
\hline & 25 - 34 year & $.87892^{*}$ & 27086 & .001 & 3462 & 1.4117 \\
\hline & 35 - 44 year & 49342 & 27830 & .077 & -.0540 & 1.0408 \\
\hline & 45 - 54 year & 30921 & 33726 & .360 & -.3541 & .9725 \\
\hline & Over 65 year & 61842 & .64580 & .339 & -.6518 & 1.8886 \\
\hline \multirow[t]{5}{*}{ Over 65 year } & 18 - 24 year & .54412 & 65096 & .404 & -.7362 & 1.8244 \\
\hline & 25 - 34 year & .26050 & .61374 & .672 & -.9466 & 1.4676 \\
\hline & 35 - 44 year & -12500 & 61706 & .840 & -1.3387 & 1.0887 \\
\hline & $45-54$ year & -30921 & 64580 & .632 & -1.5794 & .9610 \\
\hline & $55-65$ year & -.61842 & 64580 & .339 & -1.8886 & .6518 \\
\hline
\end{tabular}

Table 7: Mean Effective_Access

\begin{tabular}{|l|l|l|l|l|l|l|l|}
\hline & $\begin{array}{l}\mathbf{1 8}-\mathbf{2 4} \\
\text { year }\end{array}$ & $\begin{array}{l}\mathbf{2 5}-\mathbf{3 4} \\
\text { year }\end{array}$ & $\begin{array}{l}\mathbf{3 5}-\mathbf{4 4} \\
\text { year }\end{array}$ & $\begin{array}{l}\mathbf{4 5}-\mathbf{5 4} \\
\text { year }\end{array}$ & $\begin{array}{l}\mathbf{5 5}-\mathbf{6 5} \\
\text { year }\end{array}$ & $\begin{array}{l}\text { Over } \mathbf{6 5} \\
\text { year }\end{array}$ \\
\hline Mean & 4.3309 & 4.6145 & 5.0000 & 5.1842 & 5.4934 & 4.8750 \\
\hline
\end{tabular}

Table 8: Post Hoc analysis of Period of Dealing With A Bank on Effective_Access - LSD Method

\begin{tabular}{|c|c|c|c|c|c|c|c|}
\hline \multirow{2}{*}{$\begin{array}{l}\text { Dependent } \\
\text { Variable }\end{array}$} & \multirow{2}{*}{$\begin{array}{l}\text { (I)Period } \\
\text { dealing with } \\
\text { bank }\end{array}$} & \multirow{2}{*}{$\begin{array}{l}\text { of }(\mathrm{J}) \text { Period } 0 \\
\text { a dealing with } \\
\text { bank }\end{array}$} & \multirow{2}{*}{$\begin{array}{l}\text { Mean } \\
\text { Difference (I- } \\
\text { J) }\end{array}$} & \multirow[b]{2}{*}{ Std. Error } & \multirow[b]{2}{*}{ Sig. } & \multicolumn{2}{|c|}{ 95\% Confidence Interval } \\
\hline & & & & & & \begin{tabular}{|l} 
Lower \\
Bound
\end{tabular} & $\begin{array}{l}\text { Upper } \\
\text { Bound }\end{array}$ \\
\hline \multirow[t]{15}{*}{ Effective_Access } & \multirow[t]{5}{*}{3 month } & 6 month & -1.26364 & .73445 & .086 & -2.7082 & .1809 \\
\hline & & 1 year & -.28889 & 69883 & 680 & -1.6634 & 1.0856 \\
\hline & & 2 years & -.52273 & .69245 & .451 & -1.8847 & .8392 \\
\hline & & $3-5$ years & -.80426 & .68037 & 238 & -2.1424 & .5339 \\
\hline & & \begin{tabular}{|l} 
More than \\
years
\end{tabular} & 5.94198 & 67550 & .164 & -2.2706 & 3866 \\
\hline & \multirow[t]{5}{*}{6 months } & 3 moths & 1.26364 & .73445 & .086 & -.1809 & 2.7082 \\
\hline & & 1 year & $.97475^{*}$ & .38565 & .012 & .2162 & 1.7333 \\
\hline & & 2 years & $.74091^{*}$ & .37396 & .048 & .0054 & 1.4764 \\
\hline & & $3-5$ years & .45938 & .35110 & .192 & -.2312 & 1.1499 \\
\hline & & \begin{tabular}{|l} 
More than \\
years
\end{tabular} & 5.32165 & .34157 & 347 & -.3502 & .9935 \\
\hline & \multirow[t]{5}{*}{1 year } & 3 months & .28889 & .69883 & 680 & -1.0856 & 1.6634 \\
\hline & & 6 months & $-.97475^{*}$ & .38565 & .012 & -1.7333 & -.2162 \\
\hline & & 2 years & -.23384 & 29798 & .433 & -.8199 & 3522 \\
\hline & & 3 - 5 year & -.51537 & .26873 & .056 & -1.0439 & .0132 \\
\hline & & $\begin{array}{l}\text { More than } \\
\text { years }\end{array}$ & $5.65310^{*}$ & .25615 & .011 & -1.1569 & -.1493 \\
\hline
\end{tabular}




\begin{tabular}{|c|c|c|c|c|c|c|}
\hline \multirow[t]{5}{*}{2 years } & 3 months & .52273 & 69245 & 451 & -.8392 & 1.8847 \\
\hline & 6 months & $-.74091^{*}$ & 37396 & .048 & -1.4764 & -.0054 \\
\hline & 1 year & .23384 & 29798 & 433 & -.3522 & 8199 \\
\hline & $3-5$ years & -.28153 & 25167 & .264 & -.7765 & .2135 \\
\hline & $\begin{array}{l}\text { More than } \\
\text { years }\end{array}$ & 5 -.41926 & 23819 & .079 & -.8877 & .0492 \\
\hline \multirow[t]{5}{*}{$3-5$ years } & 3 months & .80426 & 68037 & 238 & -.5339 & 2.1424 \\
\hline & 6 months & -.45938 & 35110 & .192 & -1.1499 & 2312 \\
\hline & 1 year & .51537 & 26873 & .056 & -.0132 & 1.0439 \\
\hline & 2 years & .28153 & 25167 & 264 & -.2135 & .7765 \\
\hline & $\begin{array}{ll}\text { More than } \\
\text { years }\end{array}$ & $5-.13773$ & 20039 & .492 & -.5319 & .2564 \\
\hline \multirow{5}{*}{\begin{tabular}{|l}
$\begin{array}{l}\text { More } \\
\text { years }\end{array}$ \\
yen
\end{tabular}} & 53 months & .94198 & 67550 & .164 & -.3866 & 2.2706 \\
\hline & 6 months & -32165 & 34157 & 347 & -.9935 & .3502 \\
\hline & 1 year & $65310^{*}$ & 25615 & .011 & 1493 & 1.1569 \\
\hline & 2 years & 41926 & 23819 & .079 & -.0492 & 8877 \\
\hline & $3-5$ years & .13773 & 20039 & .492 & -.2564 & .5319 \\
\hline
\end{tabular}

Table 9: Post Hoc analysis of Period of dealing with a bank on Commodities - LSD Method

\begin{tabular}{|c|c|c|c|c|c|c|c|}
\hline \multirow{2}{*}{$\begin{array}{l}\text { Depende } \\
\text { nt } \\
\text { Variable }\end{array}$} & \multirow[t]{2}{*}{$\begin{array}{l}\text { (I) Period dealing } \\
\text { with the bank }\end{array}$} & \multirow{2}{*}{$\begin{array}{l}\text { (J) Period dealing with } \\
\text { the bank }\end{array}$} & \multirow{2}{*}{$\begin{array}{l}\text { Mean } \\
\text { Difference (I-J) }\end{array}$} & \multirow{2}{*}{ Std. Error } & \multirow{2}{*}{ Sig. } & \multicolumn{2}{|l|}{\begin{tabular}{|l}
$95 \%$ \\
Interval \\
\end{tabular}} \\
\hline & & & & & & $\begin{array}{l}\text { Lower } \\
\text { Bound }\end{array}$ & $\begin{array}{l}\text { Upper } \\
\text { Bound }\end{array}$ \\
\hline \multirow{21}{*}{$\begin{array}{l}\text { Commod } \\
\text { ities }\end{array}$} & \multirow{5}{*}{3 months } & 6 months & -.20727 & 58591 & .724 & -1.3597 & .9451 \\
\hline & & 1 year & .07111 & .55750 & .899 & -1.0254 & 1.1676 \\
\hline & & 2 years & .60364 & .55240 & 275 & -.4829 & 1.6901 \\
\hline & & $3-5$ years & 15191 & .54277 & .780 & -.9156 & 1.2195 \\
\hline & & More than 5 years & -.00061 & .53889 & .999 & -1.0605 & 1.0593 \\
\hline & \multirow[t]{5}{*}{6 months } & 3 months & 20727 & .58591 & .724 & -.9451 & 1.3597 \\
\hline & & 1 year & 27838 & 30766 & .366 & -.3267 & .8835 \\
\hline & & 2 years & $.81091^{*}$ & .29833 & .007 & .2241 & 1.3977 \\
\hline & & $3-5$ years & .35919 & 28009 & .201 & -.1917 & .9101 \\
\hline & & More than 5 years & .20666 & .27249 & .449 & -.3293 & .7426 \\
\hline & \multirow{5}{*}{1 year } & 3 months & -.07111 & .55750 & .899 & -1.1676 & 1.0254 \\
\hline & & 6 months & -.27838 & 30766 & .366 & -.8835 & .3267 \\
\hline & & 2 years & $.53253^{\star}$ & 23772 & .026 & .0650 & 1.0001 \\
\hline & & $3-5$ years & .08080 & .21438 & .706 & -.3408 & .5025 \\
\hline & & More than 5 years & -.07172 & .20434 & .726 & -.4736 & 3302 \\
\hline & \multirow[t]{5}{*}{2 years } & 3 months & -.60364 & .55240 & .275 & -1.6901 & .4829 \\
\hline & & 6 months & $-.81091^{*}$ & 29833 & .007 & -1.3977 & -.2241 \\
\hline & & 1 year & $-.53253^{*}$ & 23772 & .026 & -1.0001 & -.0650 \\
\hline & & $3-5$ years & $-.45172^{*}$ & 20077 & .025 & -.8466 & -.0568 \\
\hline & & More than 5 years & $-.60425^{*}$ & 19001 & .002 & -.9780 & -.2305 \\
\hline & $3-5$ years & 3 months & - & .54277 & .780 & -1.2195 & .9156 \\
\hline
\end{tabular}




\begin{tabular}{|c|c|c|c|c|c|c|}
\hline & 6 months & -.35919 & .28009 & .201 & -.9101 & .1917 \\
\hline & 1 year & -.08080 & 21438 & .706 & -.5025 & 3408 \\
\hline & 2 years & $.45172^{*}$ & 20077 & .025 & .0568 & .8466 \\
\hline & More than 5 years & -.15253 & .15986 & .341 & -.4669 & .1619 \\
\hline \multirow[t]{5}{*}{ More than 5 years } & 3 months & .00061 & .53889 & .999 & -1.0593 & 1.0605 \\
\hline & 6 months & -.20666 & 27249 & .449 & -.7426 & .3293 \\
\hline & 1 year & .07172 & .20434 & .726 & -.3302 & .4736 \\
\hline & 2 years & $.60425^{\star}$ & .19001 & .002 & .2305 & .9780 \\
\hline & $3-5$ years & .15253 & .15986 & .341 & -.1619 & .4669 \\
\hline
\end{tabular}

Table10: The modified BSQ instrument

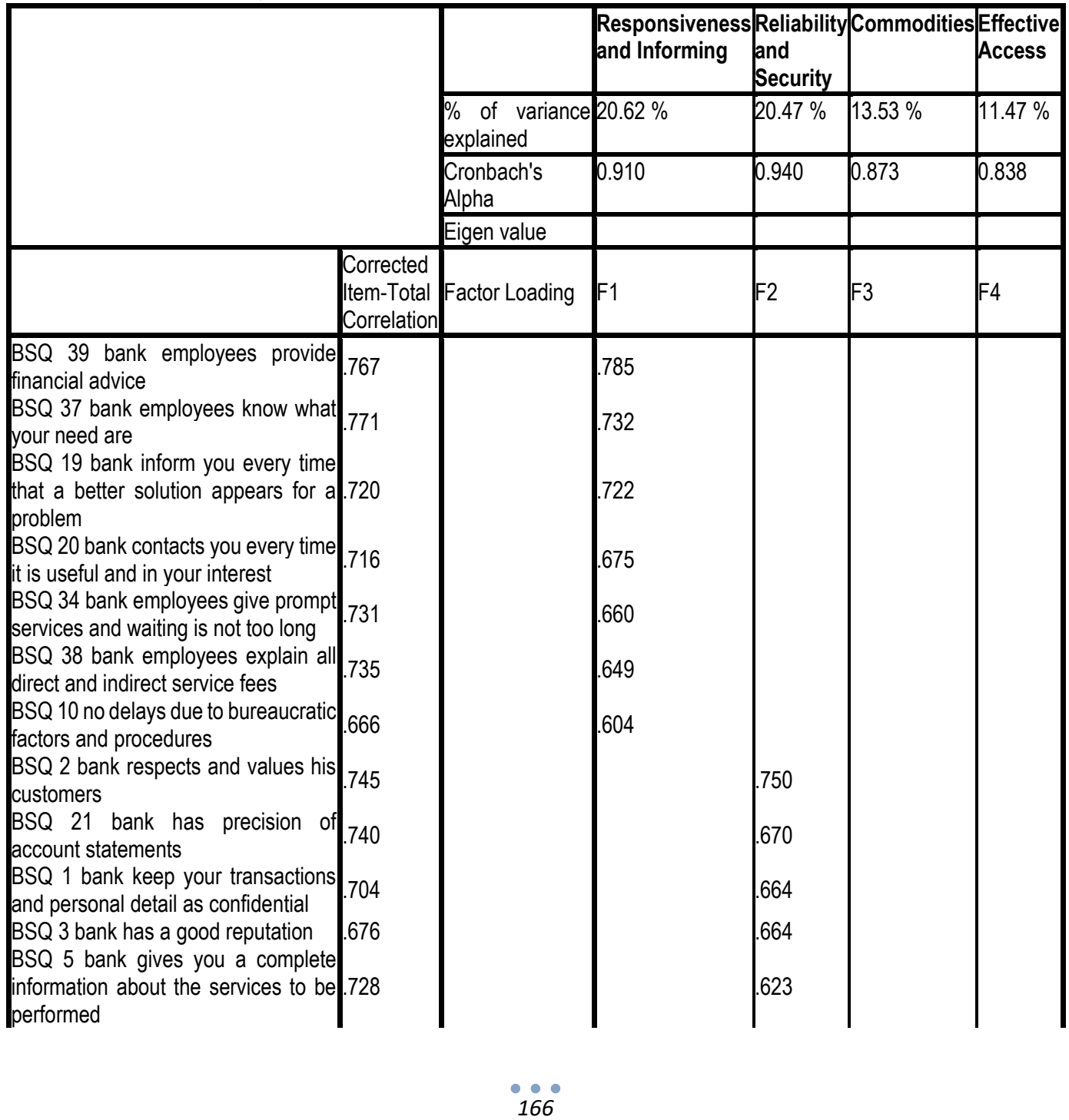




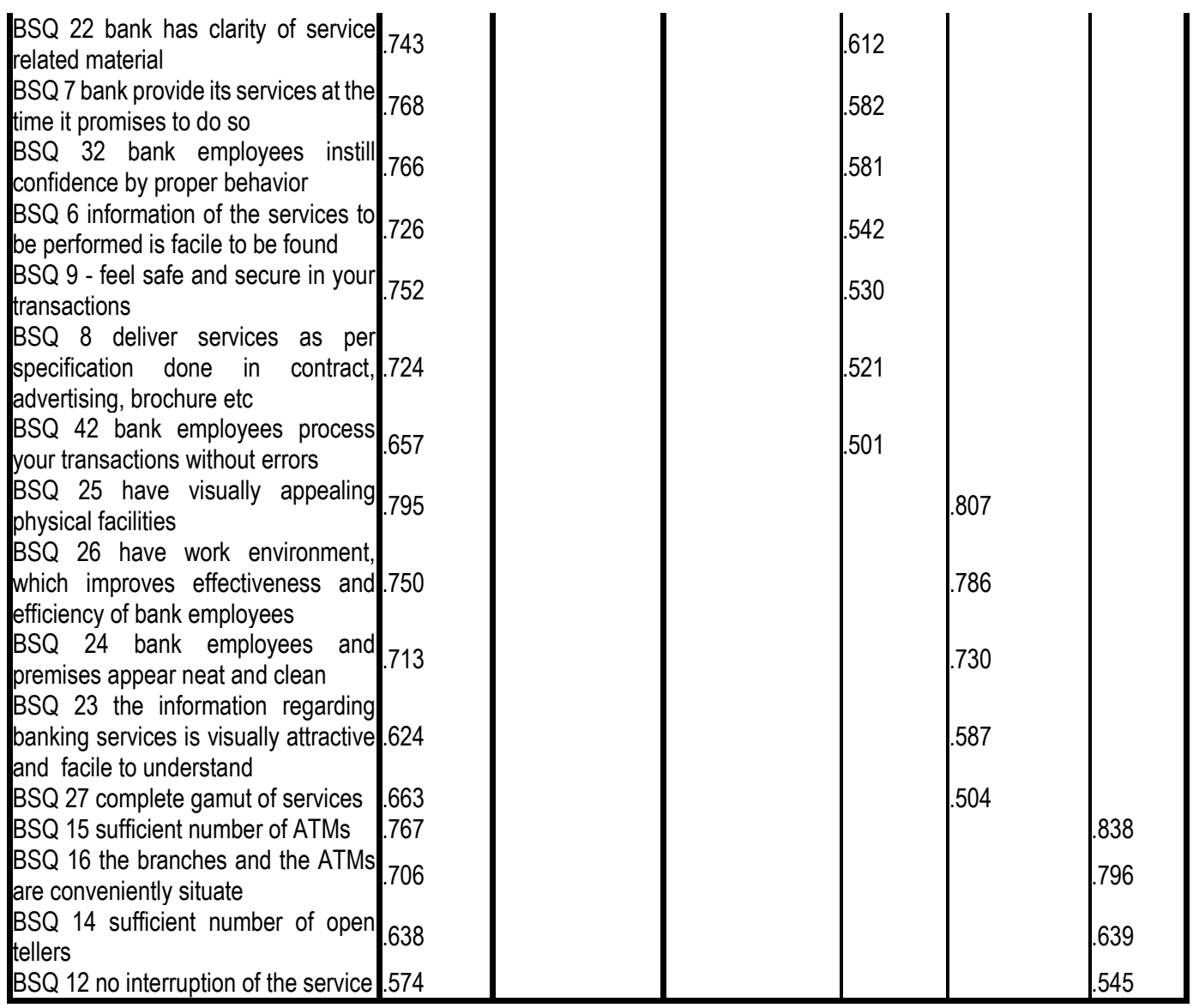

